\title{
AMMATTITAITO KASVAA - KUINKA KÄY SIVISTYKSEN?
}

Laman aikana yrityksille on tullut muotisanaksi "back to basics" ja siihen olennaisesti liittyen keskittyminen ydinosaamiseen.

Ydinosaaminen tarkoittaa yrityksen kannalta sitä, että keskitytään tuottamaan vain niitä tuotteita tai palveluksia, joihin yrityksessä oleva ydinosaaminen viittaa ja kaikesta muusta luovutaan tai tarvittavat palvelut ostetaan ulkopuolisilta yrityksiltä. Siivous- ja kunnossapitotoiminnot ovat ehkä eniten kohdanneet näitä ydinosaamiseen keskittymistä tukevia "outsourcing" toimenpiteitä.

Työtä tekevän ihmisen osalta ydinosaamiseen keskittyminen tarkoittaa usein keskittymistä siihen ammattitaitoon, jota työn tekeminen ensisijaisesti edellyttää. Näin siitä huolimatta, että yritysjohtajat julkisissa puheissaan korostavat tiimityön ja kokonaisuuksien hallinnan merkitystä.

Näyttäisi siltä, että monissa yrityksissä ollaan palaamassa tieteellisen liikkeenjohdon oppien pariin. Tällä kertaa vain opin nimi on Lean -production, nettotuotanto. Lean -yritys laihduttaa kaiken ylimääräisen pois ja puristaa ihmisen kireiden aikataulujen ja olemattomien välivarastojen pihteihin.

Ydinosaava lean -yritys ei tietenkään panosta koulutuksessa muuhun, kuin aivan välttämättömään, joka sekin annetaan pistemäisenä täsmäkoulutuksena vain sinne, niissä sitä todella tarvitaan. Esimerkiksi hitsaaja pääsee kurssille, kun hitsausmateriaalien käytössä tarvitaan uusia tekniikoita tai kirjanpitäjä silloin, kun lainsäädäntö tai ATK -ohjelmistot muuttuvat. Eikä tässä tietenkään ole mitään väärää, päinvastoin, varastoon ei kannata kouluttaa.

Ongelma syntyy, kun ryhdytään pohtimaan, kuinka käy sivistyksen. Jaksavatko jatkuvassa työpaineessa elävät ihmiset enää sivistää itseään vapaa-ajallaan, vai pitäisikö työnantajan huolehtia työntekijöidensä sivistämisestä?

Sivistys on ihmiseksi tulemisen prosessia. Se on oman ajattelun kehittämistä ja tietämisen kokonaisuutta. Ulkoisesti sivistys on hyvää käytöstä ja hyvien tapojen noudattamista. Sivistys on myös kulttuurin tuntemusta ja kulttuuristen viestien vastaanottamista ja ymmärtämistä. Sivistys syntyy laaja-alaisesta kiinnostuksesta ihmisiä ja kulttuureja kohtaan sekä omasta sisäisestä ajattelusta ja tiedonkäsittelystä.

Muistanemme Eliza Doolittlen, opettajan, professorin, joka puhui sivistyneesti ja osasi käyttäytyä kaikin puolin muutenkin sivistyneesti, mutta osoitti oman sivistyksensä rajoittuneisuuden tehdessään tieteellistä tutkimusta ja käyttäytyessään epäinhimillisesti tutkimuskohdettaan kohtaan.

Onko meistä kaikista tulossa huonosti sivistyneitä "professoreja" keskittyessämme yhä enemmän oman ammattimme vaatimaan kehittymiseen? 
Moni todistaa sivistyneisyyttään taulukokoelmalla tai ahkeralla oopperassa käymisellä. Onko taiteen bongaaminen sivistyneisyyttä? Mielestäni ei. Sivistyneisyyttä on oivaltaa taiteen lähettämä viesti ja yhdistää se omaan elämäänsä.

Yritykset ja yhteisöt voivat auttaa työntekijöitään sivistymisprosesseissa järjestämällä työ ja toiminta työpaikalla sivistymisen mahdollisuuksia tarjoavaksi vuorovaikutus ja vaikuttamismahdollisuuksia lisäämällä. Mutta olisiko tässä sivistyneisyyden kriisissä lisäksi tarvetta vapaan sivistystyön ja yritysten verkostoitumiselle? Voisiko yrityksissä kehitellä sivistyssuunnitelmia (vapaaehtoisesti) samalla tavalla kuin tasa-arvosuunnitelmia, yhteistyössä vapaan sivistystyön kanssa? Yritykset eivät voi järjestää taiteen filosofian kursseja, mutta ne voivat kannustaa ja tukea työntekijöitään prosesseissa, joissa tavoitteena on oman ajattelun ja sydämen sivistyksen kehittäminen.

Sivistyksen uudelleen herättäminen vaatii toki muunlaistakin työtä, kuin kurssien järjestämistä. Onhan niin, että ne, jotka eniten sivistyneisyyttä kaipaisivat, eivät kursseille osallistu. Sivistyksen olisi tultava sinne, missä ihmiset ovat ja pystyttävä herättämään kiinnostusta ja saamaan ihmiset mukaan. Kauniit ja rohkeat eivät tarjoa sivistystä kenellekään, mutta olisiko kauniiden ja rohkeiden viestintätavasta syytä ottaa oppia myös sivistystyön kentässä. Olisiko vihdoin tullut aika, jolloin sivistystä voitaisiin popularisoida? Itse uskon, että Martin Heideggerin elämäntyötä kuvaava sarjakuvateos sivistää ihmisiä enemmän, kuin kaikki sadattuhannet sivut, mitä filosofiasta on kirjoitettu.

Ilman sivistystä kansakuntamme kilpailukyky ei pitkällä tähtäimellä tule kehittymään. Huonosti käyttäytyvän ja toisista kulttuureista välinpitämättömän barbaarikansan kanssa ei tulevaisuudessa haluta tehdä kauppaa.

On turha kuvitella, että taloudellisten tavoitteiden saavuttaminen lisäisi sivistyneisyyttä. Taloudellinen hyvinvointi helpottaa kyllä sivistyksen leviämistä, mutta ei takaa sitä. Todellinen sivistys lähtee inhimillisten arvojen asettamisesta taloudellisten arvojen edelle ja taloudellisen menestyksen näkemisestä sivistyksen seurauksena ei sen aikaansaajana. 